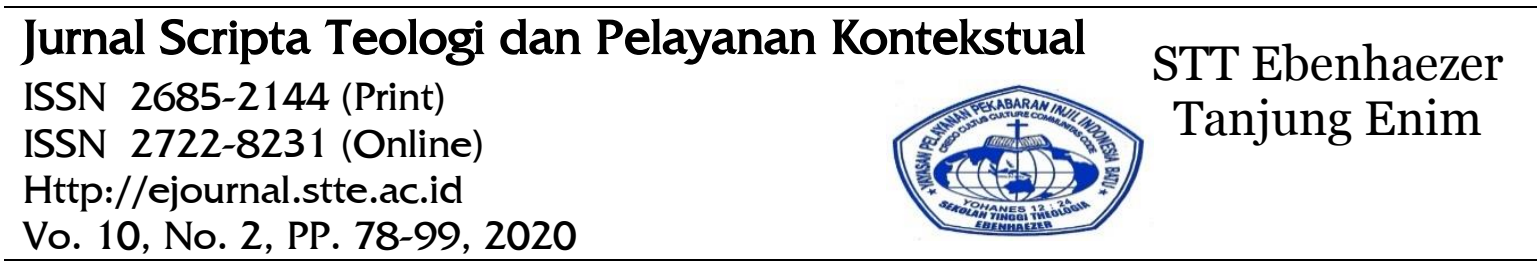

\title{
Model Pendampingan Pastoral Terhadap Perempuan Kristen Dalam Menghadapi Fase Pre-Menopause Di GPIN "Yerusalem" Palembang Lilik Utari
}

Mahasiswa Pascasarjana Institut Injili Indonesia Ip2mebenhaezer@gmail.com

\section{INFO ARTIKEL}

Sejarah Artikel:

Diterima : 13-11-2020

Direvisi : 16-11-2020

Disetujui: 24-11-2020

Dipublikasi: 28-11-

2020

Kata Kunci:

Model, Pastoral,

Perempuan, Pre-

Monopause

Keywords:

Model, Pastoral,

Woman, Pre-

Monopause

\begin{abstract}
Abstrak
Pendampingan pastoral adalah suatu pendekatan bagi setiap orang untuk mengetahui setiap kehidupan konseling oleh konselor. Tetapi berbicara tentang pendampingan pastoral Kristen itu berarti berbicara tentang bagaimana gembala melayani seseorang yang mengalami suatu masalah dalam hidupnya. Dimana dalam pelayanan ini ada beberapa pendekatan yang dilakukan, untuk bisa menemukan titik temu akan masalah yang dihadapi, terkhusus bagi seorang perempuan yang dilayani. Termasuk juga perempuan dalam lingkup gereja. Artikel ini juga akan memaparkan secara singkat tentang model pendampingan pastoral terhadap perempuan Kristen dalam menghadapi fase pre-menopause.
\end{abstract}

Abstract

\section{PENDAHULUAN}

Manusia adalah makhluk ciptaan Allah yang unik dan mulia. Kejadian 1: 26 "Berfirmanlah Allah: Baiklah kita menjadikan manusia menurut gambar dan rupa kita .....". Hal ini menunjukkan bahwa Allah adalah inisiator untuk menciptakan manusia, Allah juga yang merancang bentuk (grand design) manusia yang diciptakan-Nya. Allah menetapkan bahwa manusia diciptakan "segambar" dan "serupa" dengan diri-Nya sendiri. Pengertian tersebut tidak dipahami dalam keadaan secara jasmaniah dan lebih tepat dipahami sebagai kesamaan sifat Allah yang dimiliki oleh manusia. ${ }^{1}$ Oleh karena manusia sebagai "gambar" dan "rupa" Allah maka hakekat manusia memiliki hati nurani, berintelektual, cerdas, serta berkuasa terhadap ciptaan yang lain. Searah dengan itu Charles C. Ryrie berpendapat bahwa:

1 Anthony A. Hoekema, Manusia Ciptaan Menurut Gambar Allah, (Surabaya: Momentum, 2008), 99. 
Karya penciptaan manusia didasarkan atas perundingan sidang Allah. Walau semua ciptaan-Nya sampai sebelum jadinya manusia dikatakan baik, namun ciptaan tersebut belum lengkap bila tanpa manusia. Manusia bukan dipikirkan-Nya kemudian, melainkan hasil pemikiran terdahulu dalam benak Allah. Setelah Allah menciptakan manusia barulah ia berkata bahwa apa yang la kerjakan adalah amat baik (Kej. 1: 31$).^{2}$

Allah menciptakan laki-laki dan perempuan. Pada awal penciptaan Tuhan memberikan mereka gender sebagai laki-laki dan perempuan. (Kej. 1: 27, 2: 7), maka Allah dalam kedaulatanNya menjadikan Adam dan Hawa sebagai pasangan, Allah menciptakan manusia.

Kehidupan perempuan dapat dibagi dalam beberapa masa yaitu bayi, masa kanakkanak, masa pubertas, masa reproduksi, masa klimakterium dan masa senium. Masingmasing masa itu mempunyai kekhususan, karena itu gangguan pada setiap masa tersebut juga dapat dikatakan khas karena merupakan penyimpangan dari masa kehidupan yang khas pula dari masa yang bersangkutan. Siklus kehidupan seorang perempuan normal akan melewati pada masa peralihan dari fase reproduksi menuju fase tua yang terjadi akibat menurunnya fungsi dalam tubuh wanita. Dalam perjalanan hidupnya seorang perempuan yang mencapai umur sekitar 45 tahun, mengalami penuaan indung telur, sehingga tidak sanggup lagi memenuhi hormon estrogen. Sistem hormonal seluruh tubuh mengalami kemunduran dalam mengeluarkan hormonnya, hal ini menyebabkan berbagai perubahan pada fisik dan psikis.

Perempuan adalah sosok yang tidak pernah lepas dari kehidupan manusia seharihari. Tanpa sosok perempuan tidak akan pernah ada di dunia ini. Kitab Kejadian 2: 18 mengkisahkan penciptaan Hawa dengan penekanan Firman: "Tidak baik kalau manusia itu seorang diri saja. Aku akan menjadikan penolong baginya yang sepadan dengan dia. Menunjuk kepada sosok seorang perempuan, Anthony A. Hoekema dalam bukunya Manusia Ciptaan Menurut Gambar Allah mengatakan bahwa: Kata ini mengimplikasikan bahwa perempuan merupakan imbangan, penunjang dan pelengkap bagi laki-laki; bahwa perempuan kuat di mata laki-laki lemah, menutupi kekurangannya dan menutupi kebutuhannya. ${ }^{3}$ Banyak orang-orang hebat yang tidak akan pernah bisa menjadi hebat tanpa didukung oleh sosok perempuan hebat di belakangnya.

Ada begitu banyak pemahaman tentang perempuan, namun semua arti atau pemahaman itu bersumber pada satu kesimpulan bahwa perempuan adalah sosok yang sangat hebat, terlepas dari segala kekurangannya. Kamus Besar Bahasa Indonesia memberikan pengertian perempuan adalah perempuan dewasa. ${ }^{4}$ Beberapa tokoh berpendapat :

1. Kiai Dahlan. Perempuan merupakan aset umat dan bangsa. Tidak mungkin membangun peradaban umat manusia apabila para perempuan hanya dibiarkan berdiam diri di dapur dan di rumah saja. ${ }^{5}$

2. Abdurahman. Perempuan merupakan manusia yang mulia dan bernilai karena memiliki sifat kemanusiaan yang tinggi. Perempuan adalah seorang ibu sekaligus pendidik yang luar biasa. ${ }^{6}$

Dari pendapat di atas menunjukkan bahwa perempuan memiliki kehidupan yang dapat diandalkan. Akan tetapi, di balik kehebatan perempuan ternyata di lapangan ditemukan persoalan atau pergumulan dalam diri seorang perempuan yaitu salah satunya pada fase menghadapi "krisis Pre-Menopause". Dikenal sebagai masa berakhirnya

${ }^{2}$ Charles C. Ryrie, Teologi Dasar 1, (Yogyakarta: ANDI, 2008), 276

3 Anthony A. Hoekema, Manusia Ciptaan Menurut Gambar Allah, (Surabaya: Momentum, 2008), 99.

${ }^{4}$ Kamus Besar Bahasa Indonesia Elektronik

${ }^{5} \mathrm{Https} / /$ Carapedia.com/ pengertian definisi Wanita info/ 2141

${ }^{6} \mathrm{Https} / /$ Carapedia.com..., 
menstruasi atau mati haid. Masa ini seringkali dianggap sebagai momok dalam kehidupan perempuan. Bagi perempuan, masa ini ibarat sinyal yang mengingatkan dirinya bahwa dirinya pasti akan menjadi tua dibarengi dengan organ reproduksi yang sudah tidak berfungsi lagi. Pada masa ini kekhawatiran atau keresahan sering muncul, bahkan ditandai dengan gejala-gejala fisik yang berdampak pada pergumulan psikologis dan spritual.

Fase menopause merupakan kondisi alami, dan itu menandai akhir dari fase melahirkan anak dalam kehidupan. Menurut Badan Kesehatan Dunia (WHO), menopause merupakan masa berhentinya haid yang permanen akibat hilangnya aktivitas folikuler ovarium. Kebanyakan perempuan menjalani fase menopause dengan gejala-gejala yang cukup ringan. Itu sebabnya, mereka menghadapinya seolah-olah mereka sedang terserang flu yang berkepanjangan. Sekelompok kecil perempuan yang beruntung menyatakan bahwa dirinya tidak mengetahui sedang mengalaminya.

\section{METODE PENELITIAN}

Dalam penelitian ini penulis menggunakan metode penelitian kualitatif. Penelitian kualitatif merupakan penelitian yang digunakan untuk menyelidiki, menemukan, mndeskripsikan dan menjelaskan kualitas atau keistimewaan dari pengaruh social yang tidak dapat dijelaskan, diukur atau digambarkan melalui pendekatan kuantitatif.(saryono, 2010).

Teknik pengumpulan data dalam penelitian ini dilakukan dengan pengamatan atau partisipasi langsung dan penelaahan dokumen.

\section{HASIL DAN PEMBAHASAN}

Dalam bagian ini, penulis mendiskripsikan pengertian pendampingan pastoral, hakikat perempuan Kristen dalam menghadapi fase pre-menopause dan rangkuman.

\section{A. Pendampingan Pastoral}

Setiap orang yang percaya kepada Tuhan Yesus Kristus adalah orang-orang yang telah diberikan hidup yang baru yaitu hidup untuk mengasihi Tuhan dan mengasihi sesama manusia seperti dirinya sendiri (Luk. 10: 27). ${ }^{7}$ Oleh sebab itu, setiap orang yang percaya kepada-Nya secara otomatis didorong oleh Roh Kudus untuk menolong sesamanya yang dalam mengatasi persoalan-persoalan kehidupan yang mereka hadapi. Salah satu bentuk pertolongan tersebut adalah pendampingan pastoral.

\section{Etimologis Pendampingan Pastoral}

Kata "pendampingan" adalah turunan dari kata dasar "damping" yang artinya adalah "dekat"; "karib"; "rapat" (tentang persaudaraan dan sebagainya). ${ }^{8}$ Kata ini juga berasal dari kata kerja "mendampingi". Pengertian "mendampingi" adalah suatu kegiatan menolong orang lain yang karena suatu sebab sehingga membutuhkan pendampingan. Orang yang melakukan kegiatan "mendampingi" disebut sebagai "pendamping".

Abineno dalam bukunya pendampingan pastoral menyimpulkan bahwa pengertian pendampingan adalah kegiatan kemitraan, bahu-membahu, menemani, membagi/berbagi dengan tujuan saling menumbuhkan dan mengutuhkan. ${ }^{9}$ Dengan memperhatikan uraian di atas, maka dapat disimpulkan bahwa yang dimaksud pendampingan adalah tidakan holistik seseorang atau lebih yang mendampingi orang lain dalam menyelesaikan masalah yang dihadapinya dalam spirit kasih dan kesejajaran.

Selanjutnya, istilah "pastoral" adalah istilah bahasa Inggris yang berarti "penggembalaan". Istilah "pastoral" dipakai sebagai kata sifat dari kata

\footnotetext{
${ }^{7}$ Alkitab.

${ }^{8}$ Kamus Umum Bahasa Indonesia Edisi Kelima, Aplikasi luring resmi Badan Pengembangan Dan Pembinaan Bahasa, Kementrian Pendidikan Dan Kebudayaan Republik Indonesia.

${ }^{9}$ Jl. Ch. Abineno, Pendampingan Pastoral, (Jakarta: BPK Gunung Mulia, 2001), 9.
} 
benda "pastor" yaitu gembala jemaat. Fungsinya mengikuti profesinya. Hal itu menunjukkan bahwa apapun yang dilakukan oleh pastor atau gembala jemaat bagi jemaat yang dilayaninya adalah tindakan penggembalaan. Agar tindakan pastoral itu mencapai maksudnya, maka studi terhadapnya terus dilakukan. Steward Hiltner menyebutkan bahwa "pastoral" pada abad ke-18 dan ke-19 memakai kata "poimenics" yang berarti studi tentang penggembalaan, karena kata ini berasal dari bahasa Yunani "poimen" yaitu kata kerja yang berarti memelihara ternak. "Poimenics" muncul bersamaan dengan sederet fungsi-fungsi penting lain dari pendeta. ${ }^{10}$ Dalam bukunya Konseling Pastoral, E.P. Gintings menuliskan bahwa penggembalaan adalah pelayanan penggembalaan umum yang mencakup kehadiran, mendengarkan, kehangatan dan dukungan praktis oleh gembala (pendeta, pastoral) sebagai pendamping. ${ }^{11}$

Dalam pokok yang sama, M. Bons-Storm menjelaskan:

\begin{abstract}
Beberapa ahli theologia sudah berusaha untuk merumuskan penggembalaan itu, umpamanya Thurneysen, dalam bukunya yang terkenal tentang penggembalaan: "penggembalaan merupakan suatu penerapan khusus Injil kepada anggota jemaat secara pribadi, yaitu, berita Injil yang dalam khotbah gereja disampaikan kepada semua orang".J.W. Herfst mengatakan bahwa tugas penggembalaan itu ialah: "menolong orang satu persatu untuk menyadari hubungannya dengan Allah, dan mengajar orang untuk mengakui ketaatannya kepada Allah dan sesamanya, dalam situasinya sendiri".H. Faber: "Penggembalaan itu ialah tiap-tiap pekerjaan, yang didalamnya si pelayan sadar akan akibat, yang ditimbulkan oleh percakapannya atau khotbahnya, atas kepribadian orang, yang pada saat itu dihubunginya". Dalam hal ini Faber tidak pertama-tama menekankan apa yang diucapkan oleh si pelayan (pendeta, penatua, dsb), tetapi bagaimana perkataan pelayan itu diterima oleh anggotaanggota jemaat, dan bagaimana itu mempengaruhi kepribadian, yaitu pikiran, perasaan, pengakuan anggota-anggota jemaat. ${ }^{12}$
\end{abstract}

\title{
2. Dasar Alkitabiah Pendampingan Pastoral
}

Kebenaran tertinggi dalam segala sesuatu dalam dunia ini adalah Alkitab, karena alkitab adalah Firman Allah yang ditulis oleh para hamba-Nya dalam waktu dan dalam ilham Tuhan. Untuk itu, segala sesuatu harus berasarkan Firman-Nya.

\section{a. Perjanjian Lama}

Salah satu contoh pelayanan pendampingan di dalam Perjanjian Lama adalah pendampingan Debora seorang hakim wanita terhadap seorang komandan pasukan Israel. Pendampingan yang dilakukan oleh Debora dikarenakan Barak ketakutan menghadapi panglima tentara Yabin yang bernama Sisera yang melengkapi diri dalam peperangan dengan senjata yang sangat menakutkan bagi seorang Barak. Ketakutan Barak sangat jelas dalam ungkapannya kepada Debora yang adalah seorang wanita Israel. Kepada Debora yang memotivasinya untuk melawan Sisera, Barak menjawab: "jika engkau turut maju aku pun maju, tetapi jika engkau tidak turut maju aku pun tidak maju." (Hak. 4: 8). Kisah tentang Debora ini merupakan contoh yang khas dari kepemimpinan seorang perempuan, sekaligus sebagai contoh pelayanan pendampingan yang sangat dramatis. Seorang wanita yang dikonotasikan sebagai sosok yang lemah justru mendampingi

${ }^{10}$ Steward Hiltner, Teologi Dan Praksis Pastoral: Ontologi Teologi Pastoral (Ed) Prof. Tj. G. Holmes, Jakarta: BPK Gunung Mulia Dan Yogyakarta: Penerbit Kanisius, 72-73

${ }^{11}$ E.P. Ginting, Konseling Pastoral: Pengembangan Kontekstual, (Badung: Bina Media Imformasi, 2009), 11.

${ }^{12}$ M. Bons-Storm. Apakah Penggembalaan itu: Petunjuk praktis Pelayanan Pastoral, (Jakarta: BPK Gunung Mulia, 1988), 19. 
seorang laki-laki gagah perkasa dalam pertempuran yang hebat melawan musuh yang sangat menakutkan bagi laki-laki.

Pendampingan Debora terhadap Barak dan pasukannya membuahkan hasil yang gemilang karena bangsa Israel dalam peperangan mereka melawan panglima Sisera meperoleh kemenangan yang luar biasa. Menurut F. F.Bruce, seorang Profesor Biblical Criticism and Exegesis dari Universitas Manchestter, Sisera kalah mutlak dalam pertempuran di Kison (Hak. 4: 15; 5: 19). Kemenangan bangsa Israel yang dipimpin oleh panglima Barak atas panglima Sisera yang dipersenjatai dengan lengkap tidak dapat dilepaskan dari kerja keras pelayanan pendampingan oleh seorang wanita yang bernama Debora. Pelayanan pendampingan Debora terbukti telah membangkitkan semangat Barak dan tentara Israel berjuang dengan sungguh-sungguh sehingga mereka memperoleh kemenangan yang gemilang. Tanpa pendampingan Debora terhadap Barak, sangat mungkin kemenangan hanyalah ilusi belaka.

\section{b. Perjanjian Baru}

Salah satu contoh pelayanan pendampingan pastoral dalam perjanjian Baru adalah pelayanan rasul Paulus terhadap anak rohaninya yaitu Timotius. Pendampingan yang rasul Paulus layankan terhadap Timotius adalah pendampingan yang konstan meskipun tidak selalu mereka bertatap muka secara langsung dan hanya dapat dilakukan melalui suratsuratnya. Timotius adalah seorang hamba Tuhan yang masih muda sangat mengasihi Tuhan Yesus sekaligus seorang yang sangat banyak kelemahannya sehingga rasul Paulus selalu mendampinginya secara rohani dengan mengirimkan surat-suuratnya kepadanya.

Beberapa kelemahan atau kekurangan Timotius dinyatakan oleh rasul Paulus dalam surat-suratnya. Dari surat-surat rasul Paulus, kita tahu bahwa Timotius adalah seorang yang pemalu sehingga rasul Paulus memberikan nasihat: "...janganlah malu bersaksi tentang Tuhan kita dan janganlah malu karena aku, seorang hukuman karena Dia, melainkan ikutlah menderita bagi Injil-Nya oleh kekuatan Allah. Dialah yang menyelamatkan kita dan memanggil kita dengan panggilan kudus, bukan berdasarkan perbuatan kita, melainkan berdasarkan maksud dan kasih karunia-Nya sendiri, yang telah dikaruniakan kepada kita dalam Kristus Yesus sebelum permulaan zaman (2 Tim. 1: 8-9). Dalam nasihatnya tentang pokok ini, rasul Paulus menempatkan dirinya selevel dengan Timotius yang adalah anak rohaninya dengan memakai kata "kita" dalam mengatasi rasa malu yang harus terus dikuasainya. Dari kata "kita" yang dipakai oleh rasul Paulus, kita mengetahui betapa kasih dan rendah hatinya rasul Paulus dalam melayankan pendampingan pastoral kepada Timotius. Selain menasihati Timotius secara langsung melalui suratnya, rasul Paulus juga mendesak jemaat di Korintus yang dilayani oleh Timotius agar mereka membuat Timotius merasa lega dan tidak menghina dia (1 Kor. 1: 10-11; bandingkan 1 Kor. 4: 17).

Selain seorang pemalu, Timotius juga seorang yang penakut. Untuk menolongnya mengatasi perasaan takut yang sangat mengganggunya, rasul Paulus mengingatkannya dengan berkata: "Allah memberikan kepada kita bukan roh ketakutan, melainkan roh yang membangkitkan kekuatan, kasih dan ketertiban (2 Tim. 1: 7). Sekali lagi, dalam mendampingi Timotius rasul Paulus selalu penuh kasih dan kerendahan hati dengan memakai kata "kita". Kelemahan-kelemahan Timotius di atas jika tidak diatasi akan sangat menghambat pelayanan yang ia layankan sebagai pelayan Tuhan yang masih muda.

Pendampingan pastoral rasul Paulus kepada Timotius tidak hanya terhadap beberapa kelemahan pribadi Timotius, tetapi juga menyangkut pola hidupnya sebagai orang yang masih muda yang sangat mungkin dikuasai oleh nafsu orang muda. Untuk pokok ini rasul Paulus menulis surat kepadanya dengan kata-kata "...jauhilah nafsu orang muda, kejarlah keadilan, kesetiaan, kasih dan damai bersama-sama dengan mereka yang berseru kepada Tuhan dengan hati yang murni. Hindarilah soal-soal yang dicari-cari, yang bodoh dan tidak layak. Engkau tahu bahwa soal-soal itu menimbulkan pertengkaran, 
sedangkan seorang hamba Tuhan tidak boleh bertengkar, tetapi harus ramah terhadap semua orang. Ia harus cakap mengajar, sabar dan dengan lemah lembut dapat menuntun orang yang suka melawan, sebab mungkin Tuhan memberikan kesempatan kepada mereka untuk bertobat dan memimpin mereka sehingga mereka mengenal kebenaran, dan dengan demikian mereka menjadi sadar kembali, karena terlepas dari jerat Iblis yang telah mengikat mereka pada kehendaknya (2 Tim. 2: 22-26a).

Sebagai orang yang masih muda, Timotius sangat rentan dengan kehidupan yang duniawi. Oleh sebab itu, rasul Paulus selalu dan selalu mengingatkan Timotius bahwa ia bukan hanya seorang yang masih muda, melainkan seorang pelayan Tuhan Yesus yang segala aspek hidupnya akan berdampak besar kepada setiap jemaat yang dilayaninya. Sebagai manusia baru, Timotius harus tetap hidup dalam karakter Kristus. Bagi rasul Paulus, manusia baru atau hidup baru tidak hanya berarti telah bangkit bersama Kristus dan berada di bawah pengaturan baru, tetapi juga pembaharuan dari hari ke hari (2 Kor. 4: 16). Bagi rasul Paulus, kemudaan usia seorang yang telah dibaharui oleh Tuhan Yesus tidak dapat dijadikan alasan untuk hidup sembrono dan membabi buta. Sebaliknya; ia menasihati Timotius dengan berkata: "Jangan seorangpun menganggap engkau rendah karena engkau muda. Jadilah teladan bagi orang-orang percaya, dalam perkataanmu, dalam tingkah lakumu, dalam kasihmu, dalam kesetiaanmu dan dalam kesucianmu (1 Tim. 4: 12). Seperti seorang ayah berhubungan dengan anak kandungnya, rasul Paulus membimbing Timotius sampai pada titik yang sangat pribadi dengan berkata: "awasilah dirimu sendiri dan awasilah ajaranmu. Bertekunlah dalam semuanya itu, karena dengan berbuat demikian engkau akan menyelamatkan dirimu dan semua orang yang mendengar engkau (1 Tim. 4: 16) .Sungguh! Suatu pendampingan pastoral yang lahir dari hati yang dikuasai oleh kasih kepada semua orang melalui Timotius.

Melalui pendampingan pastoral rasul Paulus yang demikian, Timotius bertumbuh dan berkembang menjadi seorang pribadi yang sangat kuat dalam mengatasi persoalanpersoalan dalam kehidupannya dan menjadi pelayan Tuhan yang sangat memberkati banyak orang, termasuk memberkati kita pada zaman ini meskipun Timotius hidup pada abad pertama. Oleh sebab itu, pendampingan pastoral adalah pelayanan yang tidak boleh diabaikan oleh setiap pelayan Tuhan dalam hidupnya.

\section{Fungsi Pendampingan Pastoral}

Fokus pelayanan pastoral konseling atau pendampingan pastoral pada zaman sekarang ini meliputi empat (4) bidang yaitu :

Pertama, Penyembuhan (healing). Yang dimaksud dengan Penyembuhan adalah salah satu fungsi pastoral yang bertujuan untuk mengatasi beberapa kerusakan dengan cara mengembalikan orang itu pada suatu keutuhan dan menuntun dia ke arah yang lebih baik daripada kondisi sebelumnya .Secara umum, pelayanan ini dilakukan sebagai jawaban atas penderitaan dan ketakutan seseorang terhadap kematian. Abineno menegaskan bahwa yang dimaksud dengan penyembuhan adalah penyembuhan manusia seutuhnya yang meliputi penyembuhan roh, tubuh dan jiwanya sebagai suatu kesatuan; relasi dengan sesamanya dan relasi dengan Tuhannya sebagai manusia religious (homo religious). Dalam mencapai penyembuhan manusia seutuhnya, konselor atau mentor dituntut untuk memahami berbagai bidang ilmu tentang kebutuhan manusia antara lain, teologi, psikologi, ilmu kesehatan dan sosiologi serta antropologi, dasar dari semua pemahaman tersebut adalah Teologi.

Kedua, Penopangan (Sustaining). Penopangan berarti, menolong yang terluka untuk bertahan dan melewati suatu keadaan yang di dalamnya pemulihan kepada kondisi semula atau penyembuhan dari penyakitnya atau tidak mungkin atau tipis kemungkinannya. Banyak orang, karena berbagai sebab mengalami kehidupan dan situasi yang sulit. Mereka bergumul dengan berbagai macam persoalan yang berat. Persoalanpersoalan tersebut bisa juga berupa persoalan rumah tangga, persoalan dalam hubungan 
suami isteri, pendidikan anak-anak termasuk persoalan pre-menopause dan persoalanpersoalan yang bisa membuat seseorang hampir-hampir putus asa. Mereka ini sadar atau tidak sadar membutuhkan bantuan. Dalam situasi seperti inilah pendampingan pastoral dituntut untuk menyatakan fungsinya bagi konseli yaitu fungsi penopangan atau fungsi penghiburan.

Mengikuti para pakar pastoral konseling, Abineno mengusulkan bantuan-bantuan sebagai berikut:

Pertama: berusaha membantu mereka dengan perkataan dan perbuatan, supaya pergumulan-penderitaan-mereka tidak bertambah berat. Kedua: berusaha menghibur dan menguatkan mereka, kalau mereka terbuka untuk bantan itu.Ketiga: berusaha memobilisasi dan menyusun kembali" tenaga-tenaga mereka yang masih ada, supaya mereka dapat menghadapi persoalan-persoalan mereka. Keempat: berusaha membantu mereka, supaya mereka dapat memulai lagi suatu hidup yang baru, dalam situasi baru, dimana mereka sekarang berada.

Ketiga, Bimbingan (guidance) Pembimbingan berarti membantu orang-orang yang kebingungan untuk menentukan pilihan-pilihan berbagai pikiran dan tindakan alternatif, jika pilihan-pilihan demikian dipandang sebagai yang mempengaruhi keadaan jiwanya sekarang dan yang akan datang. Bimbingan atau bantuan pendampingan dalam pelayanan pastoral konseling sangat dibutuhkan oleh konseli yang menghadapi hal-hal yang sulit.

Dalam situasi yang sulit, biasanya konseli sulit untuk melihat inti persoalannya secara obyektif. Pengaruh perasaan (emosi) dan prasangka seringkali jauh dari fakta-fakta. Oleh sebab itu, tidak jarang konseli seringkali mengatakan sesuatu yang berbeda dari apa yang ia maksudkan. Pada situasi seperti inilah bimbingan atau tuntunan sangat dibutuhkan agar konseli dapat melihat apa yang dialaminya secara obyektif dan menemukan solusinya secara tepat. Ibarat mendampingi orang yang sedang berjalan, dalam pembimbingan, konselor tidak diperkenankan untuk mendikte, (mendahului) atau mengiyakan semua kemauan konseli (di belakang) konseli tetapi "harus berada atau berjalan" (dalam arti kiasan) di sisi konseli. Pendampingan pastoral adalah kebutuhan setiap orang yang sedang menghadapi persoalan-persoalan sulit dan berat dalam hidup mereka. Pendampingan pastoral sangat dibutuhkan ketika tekanan dan ketegangan hidup ini mempengaruhi tubuh dan jiwa. Pendampingan Pastoral berhubungan dengan manusia dan lingkungannya, tetapi biasanya lebih khusus dengan manusia dan lingkungannya yang sedang bermasalah.

Keempat, Pendamaian (reconciling). Pendamaian berupaya membangun ulang relasi manusia dengan Allah dan relasi manusia dengan sesamanya.

\section{Tujuan Pendampingan Pastoral}

Pada hakekatnya pendampingan adalah proses penjumpaan antara pendamping dengan orang yang didampingi yang bertujuan untuk menolong orang yang didampingi agar dapat menghayati keberadaannya dan mengalami pengalamannya secara utuh dan penuh sehingga dapat menggunakan sumber-sumber yang tersedia untuk berubah, bertumbuh dan berfungsi secara fisik, mental, spiritual dan sosial. Dari hal ini dapat dilihat bahwa pendampingan merupakan proses perjumpaan yang dinamis. Dari pemahaman tersebut, ada lima tujuan pendampingan yang menjadi perhatian dalam pendampingan. Lima tujuan pendampingan tersebut meliputi:

a. Berubah Menuju Pertumbuhan

Dalam pendampingannya secara berkesinambungan memfasilitasi orang yang didampingi menjadi agen perubahan bagi dirinya dengan lingkungannya.

\section{b. Mencapai Pemahaman Diri Secara Penuh dan Utuh}


Memahami kekuatan dan kelemahan yang ada dalam dirinya serta kesempatan dengan tantangan yang ada di luar dirinya dan dasarnya merupakan pondasi yang paling cocok bagi pertahanan secara utuh, penuh dan berkelanjutan.

\section{c. Belajar Komunikasi yang Lebih Sehat}

Banyak orang dalam kehidupan ini tidak atau kurang mampu berkomunikasi secara sehat dengan lingkunganya tetapi pendampingan dan konseling mampu berkomukasi secara lebih sehat dengan lingkungannya. Dengan membutuhkan pelatihan komunikasi secara formal dan terstruktur antara lain melalui pendampingan.

\section{d. Dapat Bertahan}

Membantu orang agar dapat bertahan pada masa kini, menerima keadaan dengan lapang dada dan mengatur kembali kehidupannya dengan kondisi yang baru bila keadaan orang yang didampingi tidak mungkin dapat kembali pada keadaan semula.

\section{e. Menghilangkan Gejala-gejala yang Disfungsi}

Membantu orang yang didampingi untuk menghilangkan dan menyembuhkan gejala yang mengganggu sebagai akibat dari krisis. Selain hal di atas tersebut, layanan pendampingan juga membutuhkan etika dan kode etik karena pendampingan pastoral merupakan pelayanan yang bersifat komprehenship yang mana para pendamping dapat membantu menghilangkan rasa susah, marah, terkejut, takut, bingung, keresahan dan putus asa yang kemudian menolong klien untuk membantukan dirinya menjadi pendamping bagi dirinya sendiri masa depan .

\section{B. Perempuan Kristen Dalam Menghadapi Fase Pre - Menopause}

Seorang yang diciptakan menjadi seorang perempuan termaksud perempuan Kristen pasti akan mengalami fase menopause yang dimulai dengan premenopause.

\section{Hakikat Perempuan Menurut Alkitab}

Istilah kata "perempuan" tersebut mencakup seluruh usia perempuan: baik anakanak, perempuan dewasa maupun lanjut usia. Sedangkan istilah "wanita" hanya menunjuk kepada perempuan dewasa. Pada hakekatnya penciptaan perempuan adalah dalam gambaran idealNya Allah, dalam rencananya, ketentuan dan kehendakNya. Wanita diciptakan sebagai sesama penyandang gambar Allah, sesama penerima dan pelaksana mandat Allah. Charles C. Ryrie menjelaskan, pertama-tama Allah mengambil tulang rusuk Adam kemudian membentuknya dalam rupa wanita

\section{a. Perempuan adalah Ciptaan Tuhan Yang Mulia}

Alkitab dengan jelas mengatakan Allah menciptakan perempuan dan laki-laki mernurut gambar dan rupa Allah. Salah satu presaposisi dasar dari pandangan Kristen tentang manusia adalah kepercayaan kepada Allah sebagai pencipta. Presaposisi ini memimpin pada pandangan bahwa pribadi manusia tidak bereksistensi secara otonom atau independen, melainkan sebagai ciptaan Allah. "Pada mulanya Allah menciptakan langit dan bumi... Maka Allah menciptakan manusia itu (Kej. 1: 1,27) "Maka Allah menciptakan manusia itu menurut gambarNya, menurut gambar Allah diciptakanNya dia laki-laki dan perempuan diciptakanNya mereka. Kata yang diterjemahkan sebagai gambar adalah tselem, dan yang diterjemahkan sebagai rupa adalah demuth. Artinya: gambar, ilisu, kemiripan, model bentuk. "Baiklah kita menjadikan manusia....". Ini mengindikasikan bahwa penciptaan manusia memiliki kelas tersendiri, karena ungkapan ini tidak dipakai untuk ciptaan lain yang manapun. Itu berarti bahwa Allah menciptakan manusia sebagai makluk yang mulia, kudus, dan berakal budi, sehingga manusia bisa berkomunikasi dengan Allah, serta layak menerima mandat dari Allah untuk menjadi menguasai segala makluk (Ke. 1:28-30). Jelaslah bahwa penciptaan Allah terhadap manusia sebagai keberadaan 
yang unik, karena dimaknainya sebagai ciptaan yang bermoral, memiliki jiwa dan kekal (Kej. 2: 7). Dengan demikian betapa luar biasanya wanita diciptakan Tuhan memiliki sifatsifat yang unik, mulia dan menyandang gambar Allah.

\section{b. Perempuan Dikasihi Allah}

Allah mengasihi para perempuan. Perempuan merupakan ciptaan-Nya yang unik, setiap perempuan diciptakan Tuhan istimewa. Gambar Allah yang tidak kelihatan dan yang dengan sempurna mencerminkan pandangan Allah atas segala sesuatu (Kol. 1: 15). Cara Yesus berinteraksi dengan para perempuan pada zamannya memperlihatkan bahwa Yesus merespek perempuan dan bahwa mereka pasti tidak setuju dengan perlakuan menindas yang begitu lazim di banyak negeri dewasa ini. Misalnya jika memperhatikan peristiwa ketika Yesus berbicara kepada seorang perempuan di dekat sumur. "Datanglah seorang wanita samaria untuk menimba air" Kata catatan Injil Yohanes dan "Yesus mengatakan kepadanya "Berilah aku minum" Yesus tidak keberatan untuk berbicara kepada seorang perempuan Samaria di tempat umum, meskipun kebanyakan orang Yahudi tidak berurusan dengan orang Samaria. Menurut The International Standard Bible Encylopedia bagi orang Yahudi" percakapan dengan seorang wanita di tempat umum khususnya dianggap suatu aib" akan tetapi Yesus memperlakukan para perempuan dengan respek serta timbang rasa dan tidak berprasangka terhadap ras atau terhadap perempuan. Sebaliknya kepada perempuan Samaria inilah Yesus untuk pertama kali memperkenalkan dirinya dengan jelas sebagai sang Mesias. Yohanes 4: 7-9,25,26. Pada peristiwa lain Yesus didekati seorang perempuan yang selama 12 tahun menderita pendarahan. Sewaktu ia menyentuh Yesus, perempuan ini langsung sembuh Yesus berbalik dan melihat perempuan itu mengatakan "Tabahlah, anak perempuan, imanmu telah membuatmu sembuh" (Matius 9: 22). Yesus tidak memaki dia, sebaliknya dengan beriba hati ia menghiburnya dan menyapanya sebagai 'anak perempuan' sungguh menenangkan hati. Dengan demikian menunjukkan bahwa peempuan sangat dikasihi Allah., bahkan Alkitab memperlihatkan respek yang tinggi terhadap perempuan, yang sangat kontras dengan pandangan dalam banyak kebudayaan zaman dahulu.

\section{c. Perempuan Sederajat dengan Laki-laki}

Perempuan sederajat dengan laki-laki (Kej. 1: 26-28), karena diciptakan dalam rupa dan gambar Allah, menerima berkat yang sama dan mandat yang sama dari Allah (Kej.1: 28). Laki-laki dan perempuan sama-sama memiliki keselamatan dalam Kristus. Dalam Galatia 3: 28 tertulis " Dalam hal ini tidak ada orang Yahudi atau orang Yunani, tidak ada hamba atau orang merdeka, tidak ada laki-laki atau perempuan, karena kamu semua adalah satu di dalam Kristus Yesus".

Sehubungan dengan hal tersebut di atas bahwa, ayat-ayat di atas memberikan penjelasan aspek-aspek kesetaraan laki-laki dan perempuan seperti dalam keselamatan, berkat, kepenuhan Roh Kudus dan pelayanan. Masih banyak lagi yang bisa digali dari Alkitab tentang kesetaraan ini. Namun meskipun kelihatan begitu banyak persamaan lakilaki dan perempuan di hadapan Allah yang bisa dipaparkan, satu hal yang pasti bahwa Allah membuat perbedaan antara laki-laki dan perempuan dalam hal kepemimpinan. Allah telah menetapkan laki-laki menjadi pemimpin bagi perempuan baik pada masa pencitaaan Adam dan Hawa (Kej. 2: 18), keluarga Kristen (Ef. 5: 23) dan gereja (1 Tim. 2: 8-15). Seperti diketahui, Tuhan mendirikan dua lembaga penting bagi umat percaya. Pertama, lembaga keluarga Kristen dan kedua, lembaga gereja. Kedua lembaga ini akan menjadi fokus di mana Tuhan memberikan petunjuk khusus tentang kepemimpinan dalam keluarga Kristen dan gereja. Jadi dapatlah dimengerti bahwa pada dasarnya Allah memberikan peran dan kesamaan dalam tugas dan tanggung jawab, di mana laki-laki dan perempuan dapat menerima semua berkat dan tanggung jawab bersama. Memiliki kedudukan dan otoritas yagn sama dihadapanNya. Dalam pandangan Tuhan Yesus bahwa wanita layak 
mendapat tempat dan kesempatan yang setara dengan laki-laki, juga dalam hal menerima anugerah keselamatan dari Allah.

\section{Peran Perempuan}

Peran berarti seseorang yang sedang memainkan bagian yang diperintahkan untuk melakukan sesuatu yang dipercayakan kepadanya. Dalam hal ini penulis mencoba melihat bagaimana tugas dan peranan yang sedang dimainkan oleh perempuan. Peneliti hanya menjelaskan beberapa peranan perempuan:

\section{a. $\quad$ Peran Perempuan Kristen Sebagai Penolong Bagi Suami}

Kekacauan peranan dan tanggung jawab antara suami dan istri sangat berpotensi menyebabkan konflik serius dan menjadi sumber berbagai persoalan dalam kehidupan keluarga. Alkitab dengan jelas menyatakan bahwa suami adalah kepala istri (Ef. 5: 22-31) dan istri adalah penolong bagi suami (Kej.2: 18). Namun tidak sedikit pasangan suami istri yang mengalami kebingungan bagaiman seharusnya menerapkan peranan tersebut dengan benar.

Untuk mendapatkan gambaran tentang status perempuan pertama sekali dikemukakan di dalam kitab Kejadian 1: 26-27 yaitu “.... baiklah kita menjadikan manusia itu menurut gambar dan rupa kita...", maka Allah menciptakan manusia itu menurut gambarNya, menurut gambar Allah diciptakanNya dia laki-laki dan perempuan diciptakanNya mereka..." ayat ini memberi arahan yang kuat bahwa tidak ada perbedaan hakekat dalam penciptaan manusia, baik laki-laki maupun perempuan. Artinya bahwa lakilaki dan perempuan itu sama di hadapan Allah.

Ketika Allah menciptakan manusia, Allah tidak memberikan batasan dalam perannya tetapi kepada jenis kelamin. Ketika manusia jatuh dalam dosa kutuk yang diberikan Allah kepada manusia yaitu laki-laki akan bekerja keras untuk menghasilkan guna kebutuhan hidup mereka, sedangkan perempuan akan sakit pada waktu persalinan atau melahirkan. Allah menciptakan Adam sebelum ia menciptakan Hawa, dan ini memang fakta tetapi bukan dalam arti manusia yang pertama lebih perkasa dibanding dengan manusia yang kedua. Lebih Dari itu yang dimaksud Allah menjadikan "penolong" lebih kepada peran wanita tersebut terhadap laki-laki. Menurut rasul Paulus dalam 1 Timotius 3: 2 "Karena itu penilik jemaat haruslah seorang yang tak bercacat, suami dari satu istri, dapat menahan diri, bijaksana, sopan suka memberi tumpangan, cakap mengajar orang lain" Alkitab memaparkan dengan jelas bahwa disatu sisi bahwa tidak ada perbedaan hakekat antara laki-laki dan pereempuan, di sisi lain ada perbedaan kebutuhan tanggung jawab dan urutan kedudukan. Dalam kitab Amsal 31: 10 dikatakan: "Isteri yang cakap siapakah akan mendapatkannya? Ia lebih berharga dari permata". Bila diperhatikan ayat di atas menjelaskan begitu penting peran isteri dalam keluarga bahagia, baik perananya terhadap suami, anak, gereja dan masyarakat. Maka tepat sekali firman Tuhan mengatakan bahwa istri yang berakal budi adalah karunia Tuhan (Ams. 19: 14). Tetapi isteri perongrong dan suka mempermalukan suami sama seperti penyakit yang membusukkan tulang (Ams. 12: 4).

Oleh sebab itu, penolong yang sepadan artinya sebagai sahabat, partner yang mendukung dan melengkapi untuk menggenapi visi Allah. Kata "sepadan" menunjukkan fungsi dan tanggung jawab yang sama besarnya, walaupun secara otoritas suami memegang peranan sebagai kepala dan istri sebagai penolong. Kata lain yang menarik adalah kata "penolong". Istilah Ibrani untuk kata penolong adalah kata "ezer" (penolong) yang mempunyai pengertian yang diungkapkan Marulak Pasaribu “

1. Tuhan memberi seorang penolong kepada laki-laki sebab Allah melihat bahwa lakilaki itu belum lengkap tanpa seorang pereempuan bersamanya, dengan kata lain 'laki-laki tanpa pereempuan belum lengkap' 
2. Kata "penolong" yang berikut sebagai pertolongan ilahi yang menyelamatkan lakilaki dari kesepian dan kesunyian. Jadi dari pengertian di atas dapat diartikan bahwa perempuan menjadi penolong ilahi bagi laki-laki sebab laki-laki tanpa perempuan belumlah lengkap.

Penunjukkan perempuan sebagai "penolong" yang Allah kehendaki yaitu Allah tidak melihat yang sesuai dengan ciptaan Allah sebelumnya, hal itu sangat nampak dari pola hidup dari ciptaan yang lain. (band. Kej.2: 18-19). Perempuan menjadi penolong bagi lakilaki, karena ada sesuatu yang tidak dimiliki oleh laki-laki, dan itu hanya dapat ditemukan pada diri perempuan. "Penolong" yang dikehendaki adalah supaya perempuan dapat mendampingi laki-laki dalam kedudukannya sebagai perempuan yaitu menolong di mana laki-laki tidak dapat lakukan. Dalam kitab Amsal 31: 10-31" hati suaminya percaya kepadanya, suaminya tidak akan kekurangan keuntungan, ia berbuat baik kepada suaminya dan tidak berbuat jahat sepanjang umurnya. Ia membeli sebuah ladang yang diinginnya dan dari hasil tangannya kebun anggur ditanamnya.."

Paulus dengan tegas mengatakan bahwa hal tersebut tidak membutikan laki-laki atas perempuan, dan bahwa Allah menciptakan hewan lebih dulu sebelum manusia (band.Kej.1: 24-28) dan tak seorangpun berpendapat bahwa hewan lebih unggul dari manusia. Akhirnya, kita catat bagian-bagian awal kitab Kejadian bahwa wanita pertama diciptakan dari rusuk manusia pertama, wanita diambil dari laki-laki dengan menunjukkan pada fakta bahwa laki-laki kehilangan sesuatu tanpa kehadiran wanita. Hanya karena Allah yang telah menentukan peranan yang berbeda untuk wanita dalam pernikahan atau pelayanan dan tidak berkaitan dengan kesamaan wanita dengan laki-laki dalam Kristus. Dimana tidak ada perbedaaan laki-laki dan perempuan (band. Gal. 3: 28).

Dengan demikian dapatlah disimpulkan bahwa perempuan/ wanita diciptakan oleh Allah yakni 'sepadan' dengan laki-laki, ia diciptakan tidak semata-mata untuk menjadi pembantu yang lebih rendah harkatnya daripada laki-laki. Artinya bahwa perempuan tidak dimaksudkan sebagai pembantu atau rekan penolong bagi laki-laki, tetapi istilah Mate dalam bahasa Inggris yang berarti dekat, maka apa yang dimaksudkan adalah untuk menjadikan suatu kuasa atau kekuatan bagi laki-laki yang dalam segala hal akan sesuai dengan laki-laki atau setara baginya.' Dan sejarah menbuktikann bahwa, dimana harkat wanita sepadan dengan laki-laki disitu kebahagiaan lebih nyata dan merata.

\section{b. Peran Perempuan Sebagai Ibu Mendidik dan Mengasihi Anak-anak}

Panggilan yang begitu besar, mulia dan sangat disenangi oleh perempuan ketika ia disebut sebagai ibu bagi anak-anaknya. Dalam hukum Ibrani kita lihat bahwa ibu harus dihormati (Band. Kel 20: 12, ia disegani (Im.19: 3 dan ditaati (Ul. 21: 18). Ia penting dalam rumah tangganya, memberi nama anak dan bertanggung jawab mendidik anak pada usia dininya.

Searah dengan itu adalah penting sekali bagi terselenggaranya rumah tangga yang baik dan rukun yaitu keluarga yang sehat dan bahagia, karena di atas yang mengatur, membuat rumah tangga menjadi surga bagi keluarga menjadi mitra sejajar yang saling menyayangi bagi suaminya. Untuk mencapai ketentraman dan kebahagiaan dibutuhkan seorang istrri yang takut akan Tuhan, dimana ia dapat menjaga suami dan anak-anaknya, serta mengatur keadaan rumah sehingga rapi, menyenangkan bagi keluarga. Anne Borrowdale mengatakan:

Perempuan merupakan agama, altar, seuntai hidup yang mengangkat. Derajat kaum suami, membesarkan anak-anak, menguduskan keluarga. Dia ingin hidup untuk orang lain dan bukan untuk dirinya sendiri. Tugas utamanya adalah mengasihi. Dia harus mengasihi dan melahirkan, itulah tugas sucinya. Baik pria maupun wanita masingmasing memproyeksikan kualitas-kualitas yang mereka kagumi dan inginkan pada diri 
lawan jenisnya. Orang memuliakan kualitas-kualitas lawan jenisnya, terlepas dari segala pemilahan. Kaum pria menampik bahwa mereka peka dan lembut, tetapi mengiginkan kualitas-kualitas seperti itu dalam diri perempuan. Sementara kaum perempuan menolak diri mereeka untuk bersifat tegas (sic), dan otoriter serta menuntut kualitas-kualitas tersebut dalam diri lelaki.

Salah satu alasan yang menyebabkan kaum perempuan merasa bahagia menerima peran melayani karena: kelihatannya sudah merupakan sifat 'alamiah' mereka untuk mengurus orang lain. Kaum perempuan adalah ibu, sehingga itu mereka diberi kemampuan-kemampuan mengasuh yang istimewa. Tentunya mengasuh dan merawat orang lain merupakan bagian yang tak terpisahkan dari peranan kaum perempuan dan sejak dini anak-anak perempuan sudah didorong ke arah itu.

Jelaslah bahwa tugas utama perempuan adalah di tengah-tengah keluarga mengurus suami dan anak-anak, karena perempuan memiliki ciri-ciri khas secara biologis yang membuat mereka cocok untuk peran-peran tersebut. Hal ini memberikan pengertian bahwa tugas para ibu bagi anak-anaknya yaitu:

1. Para ibu harus membiasakan melakukan perbuatan-perbuatan terouji pada anak

2. Para ibu harus memiliki moralitas sebagai jalan pendidikan untuk putra-putri mereka

3. Para ibu harus menanamkan pada anak-anak rasa hotmat pada orang tua mereka.

Dan ada banyak lagi tugas-tugas yang penting untuk menjadikan dan mendidik anakanak untuk hidup mengasihi Tuhan bahkan seringkali kegagalan diakibatkan peran ibu tidak dapat melakukan fungsi perannya dengan baik artinya waktu dan komunikasi tidak terjalin dengan baik. Komunikasi yang harus terus dibangun dalam sebuah keluarga, sekalipun laki-laki dan perempuan mempunyai cara yang berbeda dalam komunikasi Bill \& Pam Farrel mengatakan: Laki-laki biasanya memulai percakapan untuk menyelesaikan masalah. Jika tidak ada masalah, tidak ada gunanya bercakap-cakap. Laki-laki merasa nyaman dalam otaknya, sehingga segalanya harus beres.

Hal seperti ini sering terjadi dalam interaksi laki-laki dan perempuan karena bagi sebagian besar perempuan, mengaitkan subjek yang satu dengan yang lain dan dengan orang-orang yang berarti dalam hidupnya adalah hal yang wajar. Ia bisa terus memiliki percakapan yang tak ada habisnya tentang berbagai masalah dengan teman sejenis.

Itu berarti isteri tidak hanya berperan terhadap hidup dan kemajuan karier suami, tetapi juga menentukan kemajuan anak. Kualitas keluarga dari sisi lain juga dapat tercermin dari kebahagiaan, pertumbuhan dan kemajuan anak, karena kehancuran dan ketidak bahagiaan rumah tangga dapat mengakibatkan anak menjadi korban. Pendapat Doktor Henry Brandt yang dikutip oleh Tim Lahaye mengatakan sebelum seseorang dapat menjadi orang tua yang mampu, terlebih dahulu ia harus menjadi pasangan yang mampu. Tetapi sebelum seorang dapat menjadi pasangan yang mampu, ia harus menjadi pribadi yang mampu. Seorang isteri yang dapat menempatkan diri sebagai seorang ibu bagi anak-anaknya apabila terlebih dahulu dapat menjadi pribadi yang bertingkah laku Kristen, didasarkan dengan hubungan yang konsisten bersama Tuhan. Keluarga yang sehat mental sangat diperlukan bagi anak-anak untuk bertumbuh secara maksimal.

Ada lima faktor diungkap oleh Paul D. Meirer, M.D supaya keluaga menjadi lingkungan yang sehat bagi pertumbuhan anak-anak, yaitu kasih, disiplin, kemantapan dalam bertindak, teladan dan suami sebagai kepala rumah tangga Setiap ibu ingin agar anak-anaknya berbahagia serta mendapatkan perlindungan dari Tuhan. Oleh sebab itu seorang ibu harus bersih kelakuannya dan takut akan Tuhan menjadi hal penting yang harus dipelihara dan dikembangkan. Firman Tuhan berkata "Orang benar yang besih 
kelakuannya, berbahagia keturunananya" (Amsal 20:7) dan "Dalam takut akan Tuhan ada ketentraman yang besar, bahkan ada perlindungan bagi anak-anaknya” (Amsal 14:26).

Kebahagiaan anak dikemudian hari, bahkan keberhasilan anak dalam pendidikan formal sangat bergantung pada pendidikan dan pengarahan yang diberikan oleh orang tuanya sendiri. Anak perlu diinjili supaya dapat bertumbuh secara rohani. Firman Allah dengan jelas meletakkan tugas pendidikan rohani anak pada orang tuanya sendiri, dalam konteks rumah tangga dan kegiatan harian (Ul. 6:4-9). Para ahli kemukakan empat kebutuhan dasar anak yang harus diartikan dan dipenuhi sedini mungkin. Pemenuhan keutuhan-kebutuhan ini, pada anak kecil mengembangkan pola hidup yang efektif dalam pembinaan selanjutnya. Dan pemenuhan kebutuhan-kebutuhan ini tidak akan tuntas kalau anak yang bersangkutan belum mnegenal Yesus. Empat kebutuhan dasar yaitu harga diri, pengenalan diri, disiplin diri dan penyangkalan diri. Peran ibu sangatlah kompeks memelihara dan mengasihi anak, menyediakan makanan bagi anak-anaknya (Amsal 31:15 a), mengasuh dan mengawasi anak (Amsal 31:27 a), bukan hanya hal itu tetapi ibu juga berperan sebagai bagi anak-anaknya. Sebagai imam berarti menyampaikan keluhan, masalah dan sukacita anak kepada Tuhan, ibu juga berperan menjadi penyambung lidah Allah, yaitu menyampaikan Firman Allah kepada anak.

Dalam sisi yang lain perlu disadari bahwa kehidupan ibu sangat mewarnai kehidupan anak yaitu menjadi teladan bagi anaknya . Perkataan, perbuatan dan gaya hidup orang tua akan diteladani anak-anak (Amsal 20:15, 14:1; 31:20). Sebagai guru seorang ibu harus dapat mendidik anak-anaknya. ' Hai anaka-anakku dengarlah didikan ayahmu dan janganlah menyia-nyiakan ajaran ibumu (Ams 1:8b) dan ditekankan lagi pada pasal 6:20 "Hai anakanakku, peliharalah perintah ayahmu dan jngan menyia-nyiakan ajaran ibumu. Sehubungan dengan kedua ayat tersebut menyakatan peran ibu sebagai guru, pendidik, pengajar, terutama untuk mengajr dan mengenalkan anak takut akan Tuhan, berarti ibu (orang tua) harus berulang-ulang menagajarkan Friman Tuhan kepada anak-anak. (Ul. 6:67).

\section{c. Contoh Perempuan Pre-Menopause Dalam Alkitab}

Di dalam Alkitab ada beberapa contoh nama tokoh perempuan pre-menopause. Diantaranya;

Kisah Abraham dan Sarah dalam pergumulan menantikan janji penggenapan Tuhan. Sarah adalah salah satu wanita yang tercatat dalam Alkitab sebagai wanita yang mandul dan sudah lanjut usia (Kejadian 18: 11). Di dalam Kejadian 17: 17 menjelaskan bahwa usia Abraham pada saat itu adalah seratus tahun sedangkan usia Sarah adalah Sembilan puluh tahun. Dengan keadaan seperti inilah yang membuat Sarah tidak percaya untuk mendapatkan keturunan. Ini terbukti dalam perkataannya di dalam Kejadian 18: 12b yang berbunyi "Akankah berahikah aku, setelah aku sudah layu, sedangkan tuanku sudah tua?".

Secara Medis, usia seratus tahun (Abraham) dan Sembilan puluh tahun (Sarah) merupakan usia yang tidak produktif lagi dalam menghasilkan keturunan. Tetapi justru Tuhan menembus kemustahilan hukum alam tersebut dengan berfirman kepada Abraham bahwa Allah akan memberkati Sarah, dan dari pada Sarah juga Allah akan memberikan kepada Abraham seorang anak laki-laki bahkan Allah akan memberkatinya, sehingga Sarah menjadi ibu bangsa-bangsa, raja-raja bangsa-bangsa akan lahir daripadanya (Kejadian 17: 16).

Elisabet adalah nama seorang perempuan Yahudi yang disebut di dalam Alkitab. Elisabet adalah isteri dari seorang imam bernama Zakharia, keduanya adalah keturunan Harun yang tinggal di sebuah kota di daerah Yudea. Lama dalam perkawinan itu mereka tidak mempunyai anak, sebab Elisabet mandul dan keduanya telah lanjut umurnya. Namun atas anugerah Tuhan, dia mempunyai seorang putera dalam masa tuanya. Hal itu terjadi setelah malaikat Gabriel menampakkan diri kepada Zakharia, "sebab doamu telah 
dikabulkan dan Elisabeth isterimu akan melahirkan seorang anak laki-laki bagimu dan haruslah engkau menamai dia Yohanes" (Lukas 1: 13).

\section{Perempuan yang mengalami fase Pre-Menopause}

Menjadi tua sering kali menjadi momok yang menakutkan bagi perempuan. Kekhawatiran ini mungkin berawal dari pemikiran bahwa dirinya akan menjadi tidak sehat, tidak bugas, dan tidak cantik lagi. Kondisi tersebut memang tidak menyenangkan dan menyakitkan. Padahal merupakan salah satu fase yang harus dijalani seorang wanita dalam kehidupannya. Keluhan tidak nyaman ini bisa disikapi secara berbeda pada setiap wanita. Apabila perempuan dapat berpikir positif , maka berbagai keluhan dapat dilalui dengan lebih mudah. Namun sebaliknya, apabila perempuan tersebut berpikir negatif, maka keluhan-keluhan yang muncul semakin memberatkan dan menekan hidupnya. Untuk itu akan dijelaskan informasi dan memahapi apa itu menopause.

\section{a. Etimologis}

Menopause berasal dari bahasa Yunani Yaitu Men Dan Pauseis yang menggambarkan berhentinya haid. Menurut kepustakaan abad 17 dan 18, menopause dianggap tidak berguna dan tidak menarik lagi. Webster' Ninth New Collllllgiate Dictionary mendefinisikan menopause sebagai periode beerhentinya haid secara alamiah yang biasanya teerjadi antara usia 40-50 tahun, atau didefinisikan secara klinis sebagai suatu periode ketika seorang perempuan tidak lagi mengalami menstruasi karena produksi hormonnya berkurang atau berhenti. Sedangkan Kata permenopause merupakan fase transisi menuju menopause yang dimulai beberapa tahun sebelum menopause terjadi. Pada periode ini, hormone estrogen akan meningkat dan menurun secara teratur. Kata yang sama dipakai untuk premenopause juga disebut perimenopause.

\section{b. Usia Pre Menopause}

Menopause adalah proses alami yang terjadi pada seorang perempuan. Walaupun rata-rata menopause terjadi usia 52 tahun, tetapi ada pula yang mengalami premenopause yakni masa transisi yang terjadi di awal usia 40 tahunan atau pertengahan 30 tahunan. Perimenopause bisa dimulai pada usia 40,30 atau lebih awal.

\section{c. Tanda dan Gejala Perempuan yang mengalami fase Pre-Menopause}

Meskipun menopause adalah tahap normal dalam hidup semua perempuan, namun menopause bisa memberikan gangguan pada sebagai perempuan yang mengalaminya. Dr. Andik Wijaya menjelaskan bahwa gangguan yang di alami seperti; Hot flashes, insomnia, melancholic, weakness, headache, palpitation, paresthesias, nervousness, vertigo, arthralagia or myalgia, dan formication.

\section{Perubahan Pola Haid}

Menstruasi irregular mungkin terjadi selama menopause. Beberapa perempuan memiliki masalah minimal dengan pendarahan abnormal selama fase pre-menopause. Pendarahan yang berlebihan terjadi jika periode menstruasi lebih sering (berarti lebih pendek durasi dalam siklusnya) atau mereka mengalami menstruasi tidak teratur (artinya siklus memperpanjang dirasi).

Perubahan siklus menstruasi atau perubahan pola haid ditandai dengan jumlah darah yang keluar saat menstruasi akan lebih banyak, lebih sedikit, atau mungkin hanya berupa flek atau spotting. Durasi menstruasi bisa menjadi lebih singkat. Spotting sangat berbahaya jika tidak diperiksakan karena bisa mengakibatkan kondisi yang lebih serius seperti kanker.

\section{Hot Flashes dan gangguan tidur}


Sekitar 75-85 persen perempuan mengalami hot flashes selama pre-menopause. Hot flashes adalah gelombang panas tubuh yang datang tiba-tiba, akibat perubahan kadar estrogen yang menerang tubuh bagian atas dan muka. Serangan ini ditandai dengan munculnya kulit yang memerah di sekitar muka, leher dan dada bagian atas, detak jantung yang kencang, badan bagian atas berkeringat, termasuk gangguan tidur. Kondisi ini biasa berlangsung antara 30 detik hingga 10 menit. Gejala ini mengakibatkan menggangu aktivitas. Gangguan tidur ini jika berkelanjutkan akan mengakibatkan muncul gejala insomnia atau kesulitan tidur.

\section{Kesuburan Berkurang}

Ovulasi atau pelepasan sel telur menjadi tidak teratur, sehingga kemungkinan bertemunya sel telur dengan sperma menjadi lebih rendah walau masih mungkin untuk hamil.

Dimasa premenopause mula-mula siklus haid akan lebih pendek dari biasanya ini karena adanya kombinasi proses pengelpasan sel telor ) ovulasi dan dimulainya siklus haid baru, yang normalnya 12-16 hari. Volume darah haid juga lebih sering. Namun akhirnya siklus haid menjadi lebih panjang ketika jumlah sel telor yang dilepaskan menjadi semakin berkurang. Volume darah haid menjadi lebih sedikit dan proses ovaluasi juga menjadi sporadic; kadang melepaskan sel telur kadang tidak.

\section{Perubahan Fungsi Sexsual}

Selama pre-menopause, keinginan untuk berhubungan intim dapat berubah, tetapi pada banyak perempuan akan mengalami masa-masa menyenangkan sebelum masa menopause tiba dan biasanya berlanjut sampai melewati masa pre-menopause. Gejala ini disebabkan penurunan kadar estrogen dapat memperlambat reaksi klitoris dan menyebabkan keringnya vagina. Kondisi ini dapat menyebabkan menurunnya gairah seksual.

\section{Perubahan Mood}

Hormon yang tidak seimbang bisa mempengaruhi kondisi emosi perempuan. Ketika kadar hormone menurun, tingkat energy pun menurun. Sehingga saat ingin memasuki masa menopause, perempuan bisa merasa kelelahan dan lemas tanpa sebab atau perubahan mood.

\section{Perubahan Kadar Kolesterol}

Berkurangnya estrogen akan merubah kadar kolesteerol dalam darah dan meningkatnya kadar kolesterol jahat (LDL) yang mengakibatkan resiki terkena penyakit jantung. Sedangkan HDL atau kolesterol baik, menurun sesuai pertambahan usia

\section{Produksi Lemak meningkat}

Masa fase pre-menopause mengakibatkan perempuan akan mengalami peningkatan lemak pada tubuh, khususnya lemak disekitar pinggang. Perubahan hormonal mengakibatkan berat badan bertambah terutama dibagian pinggang. Penurunan kadar estriogen menyebabkan tubuh lebih lama mempertahankan lemak. Selain itu rendahnya tingkat testosterone juga menyebabkan penurunan system metabolism dan mengakibatkan penambahan berat badan.

\section{Nyeri saat berhubungan}

Jika perempuan sudah memasuki masa fase pre-menopause, ada yang mengalami rasa sakit berhubungan badan, dan ini dikarnakan miss $\mathrm{V}$ tidak basah lagi. Perubahan hormone berarti dinding vagina mengalami pengurangan jumlah cairan yang diproduksi serta elastistasnya. Bebarapa perempuan dapat merasa hal ini begitu tidak nyaman, 
namun banyak juga yang baru menyadari saat melakukan hubungan seksual. Tak hanya itu lamanya waktu yang dibutuhkan untuk merasa terangsang juga meningkat seiring bertambahnya usia.

\section{d. Faktor Perempuan Yang mengalami fase Pre-menopause}

Cepat atau lambat perempuan pasti akan mengalami menopause. Namun tak ada rumusan pasti mengenai kapan datangnya proses fisiologi ini.

\section{Faktor Merokok}

Terjadinya fase menopause pada 1-2 tahun lebih awal pada perempuan yang merokok, dibandingkan dengan perempuan yang tidak merokok. Para Ahli mengatakan bahwa bahwa perempuan perokok ada kaitannya antara meroko dengan menopause.

\section{Faktor Keturunan}

Perempuan cenderung mengalami menopause sekitar usia yang sama dengan ibu atau saudaranya, meskipun hubungan antara riwayat keluarga dan usia menopause masih perlu penelitian lebih lanjut.

\section{Kemoterapi dan Terapi Radiasi}

Terapi kanker dapat memicu menopause, menyebabkan gejala seperti hot flashes selama pengobatan atau dalam jangka waktu 3-6 bulan. Penggobatan kanker seperti kemoterapi atau terapi radiasi panggul juga termasuk sebagai factor penyebab menopause dini. Efek samping yang ditimbulkan kemoterapi ini bisa menimbulkan kerusakan pada ovarium dan menyebabkan ovarium berhenti bekerja, namun ini bergantung frekuensi kemoterapi yang dijalani.

\section{Tidak pernah melahirkan}

Beberapa penelitian menunjukkan bahwa wanita yang tidak pernah menlahirkan dapat menebabkan menopause diri karena siklus masa haid tidak beraturan dan kurangnya kesuburan dalam dirinya. Perhitungan siklus haid menjadi terlambat atau banyak mengakibatkan hormon meningkat.

\section{e. Dampak Perempuan yang mengalami fase Pre-Menopause}

Pada bagian ini akan dijelaskan dampak yang dialami oleh seorang perempuan yang mengalami fase premenopause, yaitu:

\section{Dampak psikologi}

Premenopause berpengaruh pada kondisi psikologis seorang perempuan, hal ini bisa disebabkan oleh perubahan hormone yang terjadi pada tubuhnya tetapi juga sangat dipengaruhi oleh pandangan dirinya tentang apa yang akan terjadi dalam hidupnya akibat akan menopause.Pikiran-pikiran negative seperti ini memberikan beban psikologi yang berat pada dirinya.

\section{a. Depresi}

Menopause adalah proses alami fisiosiklus berhentinya menstruasi sejalan dengan lanjutnya usia seorang perempuan. Rata-rata pereempuan mengalami menopause pada usi antar 40-50 tahun, yang disertai dengan penurunan produksi hormon estrogen secara sifnifikan. Namun dalam menyikapi masa ini ada banyak wanita mengalami dipresi seperti kecemasan berlebihan, paranoia, mudah marah dan tersinggung oleh hal-hal yang sepele, merasa dirinya adalah beban, sedih berlebihan dan tertekan dan selalu berpikir negatif higga sulit tidur. 
Oleh sebab itu dapak psikologis tersebut harus benar-benar dipantau agar perempuan yang memasuki periode menopause tidak kehilangan semangat hidupnya dan berujung pada keinginan mengakhiri hidup atau penyakit fisik seperti kanker, jantung koroner dan hipertensi.

Ternyata gejala depresi saat menopause lebih banyak teerjadi pada perempuan yang memiliki daya adaptasi yang reendah terhadap perubahan, akibatnya stres berkepanjangan karena sindrom menopausepun tidak bisa dihindari. Miriam Neff mengatakan : depreesi tidak sama untuk setiap orang. Para psikolog dan kalangan medis menggunakan rumusan yang menyangkut gejala-gejala yang dapat diamati.

Oleh sebab itu bagi wanita yang menilai atau menganggap menopause itu sebagai peristiwa yang menakutkan (stressor) dan berusaha untuk menghindarinya, maka strespun sulit di hindari. Ia akan sangat menderita kareena kehilangan tanda-tand kewanitaan yang selama ini dibanggakan. Sebaliknya bagi wnita yang menganggap menopause sebagai suatu ketentuan Allah yang akan dihadapi, semua wanita, maka ia tidak akan mengalami stres atau kemungkinan stres yang dialami tidak seberat dibanding wanita yang mempersepsikan menopause itu sebagai 'momok' atau 'kiamat'. Dengan demikian setiap wanita yang menyikapi dengan baik akan menekan tingkat depresi dan gejalagejala itu akan menghilang dengan sendirinya.

\section{b. Takut Ditinggalkan}

Sebagai perempuan merupakan hal yang wajar jika pada saat pre-menopause mempunyai pikiran-pikiran yang menghantuainya, dan perasaan itulah yang menggiring wanita untuk mengalami perasaan perasaan negatif saat mengalami menopause. Perasaan negatif yang sering menyertai ialah tidak cantik lagi, tidak berharga, tidak dibutuhkan, sehingga takut ditinggalkan oleh suami dan sebagainya. Ketakutan semacam itu justru akan semakin memperburuk keadaan sebab pikiran negatif akan menimbulkan hal yang negatif pula. Oleh karena pre - menopause akan dihadapi oleh semua wanita, maka wanita lebih mempersiapkan diri untuk memahami semua gejala -gejala dengan baik

\section{c. Merasa Tidak Berarti (tidak percaya diri)}

Wanita menopause mengalami gangguan mood yang signifkan. Menopause adalah saat perubahan, bagaimanapun, dan reaksi emosional adalah bagian dari itu. Memperhatiakn perubahan dalam tubuh dapat memicu kekhawatiran tentang daya tarik dan citra tubuh. Bagi beberap orang meskipun prosesnya sedikit lebih bergerigi. Hampir seperempat wanita mengalami perubahan suasana hati sebelum, seslama atau seteelah menopause. Yang komplikasi oleh kareena perubahan diri merasa tidak berarti lagi dan kehilangan kepercayaan diri maka hal yang ppaling komplikasi untuk mengatasi kehidupan mereka dan perubahan mood menopause beberpa wanita mungkin memutuskan untuk 'mengobati sendiri' dengan alkohol atau obat lain.

\section{Dampak Spritual}

Perempuan yang akan mengalami menopause, fase premenopause secara umum memiliki kesadaran lebih tinggi akan fakta penuaan, kematian, serta kehidupan kekal. Jika seorang perempuan tidak bisa menerima kondisi ini maka menjadi terganggu pada dirinya, yaitu:

\section{a. Lebih mengasihani diri sendiri}

Kondisi ketidaknyaman dan serangan penyakit yang di alami perempuan pada fase premenopause mengakibatkan dirinya menjadi pribadi yang tertutup dan tidak stabil dalam kejiwaannya. Lebih banyak mengasihani dirinya sendiri. Tidak bisa merasakan kehadiran orang-orang disekitarnya. Apa pun pendapat dan saran dari orang lain kadang 
tidak ditanggapi positif malah sebaliknya kecurigaan dan ketidaksenangan karena dirinya merasa terganggu.

Kondisi ini juga bisa membuat seorang perempuan yang mengalami fase krisis premenoupause jarang mengikuti kegiatan-kegiatan persekutuan dalam kategorial gereja. Lebih memanjakan diri untuk memberikan alasan tidak hadir 'sakit atau tidak berdaya'.

\section{b. Menyalahkan Tuhan}

Masa transisi yang berat yang dialami seperti pendarahan yang lama dalam menstruasi, serangan penyakit 'sakit kepala, bagian perut, susah tidur' membuat ketidakseimbangan rohani. Akibatnya tidak siap dan menyalahkan Tuhan. Ada seorang ibu yang hampir 2 tahun mengalami masa pre-menopause yang sangat berat mengakibatkan dirinya sakit, berat badan turun, kecemasa, kesulitan-kesulitan tidur menyalahkan Tuhan; menganggap penyakit ini karena dosa dan hal-hal lainnya.

\section{Dampak Sosial}

Sebagian perempuan menarik diri dari komunitas sosialnya, ketika akan mengalami menopause.

\section{a. Dengan pasangan}

Selama pre-menopause, keinginan untuk berhubungan intim dapat berubah, tetapi pada banyak perempuan akan mengalami masa-masa menyenangkan sebelum masa menopause tiba dan biasanya berlanjut sampai melewati masa pre-menopause. Gejala ini disebabkan penurunan kadar estrogen dapat memperlambat reaksi klitoris dan menyebabkan keringnya vagina. Kondisi ini dapat menyebabkan menurunnya gairah seksual. Masa haid yang tidak stabil dan sebagian yang menyatakan sulit dan nyeri ketika berhubungan. Hal inilah yang mengakibatkan hubungan dengan pasangan bisa menjadi renggang bahkan tidak harmonis.

Suami yang tidak mengetahui dan memahami tentang masa premenoupase istrinya bisa menimbulkan kecurigaan dan ketidakpuasan. Suami bisa putus asa dalam mendampingi istrinya. Istri menjadi pribadi yang berbeda sebelumnya, sehingga suami tidak bisa memahami diri istrinya.

\section{b. Dengan keluarga besar}

Perasaan tidak mood dan kurang tidur, mengakibatkan suasanan hati untuk berkomunikasi dan berelasi menjadi terganggu. Kesulitan untuk memberikan waktu, kesulitan untuk mengungkapkan keinginan bisa menimbulkan kesalahpahaman.

Hubungan dengan anak-anak dan keluarga besar sangat terganggu. Jika seorang perempuan mengikuti proses terapi untuk mengatasi masa ini, itu jika menjadi persoalan di kedua belah pihak.

\section{Model Pendampingan pastoral terhadap perempuan Kristen dalam menghadapi fase pre-menopause di GPIN "Yerusalem" Palembang}

\section{Model Pendampingan Pastoral}

Pendampingan pastoral mempunyai arti sebuah proses yang dilakukan oleh seseorang yang bersedia untuk memberikan perhatian, perawatan, pemeliharaan, perlindungan kepada seseorang yang membutuhkan. Tujuan pendampingan pastoral adalah untuk mengaktualisasi kasih Allah dalam kehidupan orang percaya. Fungsinya pendampingan pastoral yaitu; menyembuhkan, menguatkan/menopang, membimbing dan memperbaiki hubungan. 
Langkah-langkah pendampinagn yaitu:

a. Meneguhkan kembali keyakinan. Dampingan bahwa orang disekitarnya tetap mengasihi, bahkan Tuhan tetap setia mengasihinya.

b. Bantulah agar dalam transaksi/negosiasi kembali yakin akan kasih Allah maupun orang-orang disekitarnya.

c. Menyadarkan bahwa setiap kondisi yang dialami Tuhan pasti tolong dan kehendak Tuhan yang mutlak.

d. Membimbing dan mendoakan agar dampingan menyerahkan hidupnya dalam iman yang tulus.

2. Pendampingan Pastoral terhadap perempuan Kristen dalam menghadapi fase Pre Menopause.

3.

\section{a. Menurut kesehatan}

Setiap perempuan pasti akan mengalami menopause. Menopause merupakan bagian dalam fase atau siklus kehidupan seorang perempuan ketika masa kesuburan dan masa reproduksi mengalami penurunan hormonal. Menopause bukanlah penyakit beerbahaya namun fase ini sering dikhawatirkan perempuan dewasa, namun bukan berarti kondisi ini bukan berarti tidak dapat disikapi. Ada beberapa cara yang peniliti ambil untuk mengaplikasinya, di antaranya;

\section{Menerapkan Gaya Hidup Sehat}

Menopause merupakan peristiwa alami dalam siklus kehidupan perempuan. Untuk mencegah berbagai keluhan yang mungkin terjadi di masa menopause yang disebabkan oleh kekurangan hormon estrogen, pengaturan pola hidup sehat yang tepat sedini mungkin adalah salah satu jawaban yang tepat untuk mengatasi kekurangan hormon estrrogen pada tubuh. Hal ini merupakan alternatif alamiah, yaitu dengan mengkonsumsi ekstra estrrogen yang terkandung banyak dalam sejumlah bahan pangan. Menopause diet adalah waktu yang baik untuk membatasi makanan yang tidak begitu bagus untuk seorang perempuan menuju masa menopause karena ransel kalori dapat lebih mudah selama fase kehidupan ini dan faktor resiko jenis penyakit tertentu bisa naik. Tidak mengkonsumsi lemak yang berlebihan dan tidak mengkonsumsi minuman yang berakohol, minuman berkafein akan memelihara hati dan membantu untuk mengurangi risiko kondisi seperti kanker dan diabetes. Bahan pangan yang kaya akan fitoestrogen adalah jenis kacangkacangan terutama kacang kedelai,serta dapat diteemukan pada hampir semua jenis sayuran, pepaya, dan tanaman lain yang kaya akan kalsium bahkan dianjurkan mengkonsumsi bengkuang, agar-agar rumput laut.

\section{Olah Raga Teratur}

Berolahraga secara teeratur banyak manfaatnya. Berolahrga memungkinkan untuk membakar lemak yang berlebihan dengan lebih efesien. Dengan demikian, olahraga membantu mengendalikan berat badan. Dengan berolahraga mendapat manfaat yang luar biasa diantaranya :

1. Meningkat fungsi kekebalan tubuh, serta kemampuan tubuh untuk menjaga kadar gula darah

2. Menjaga kepadatan tulang, menjaga massa otot, membakar lemak, mengurangi stress, mengurangi gejala menopause misalnya meriang

3. Membantu menjaga fleksibilitas dan kelenturan sendi sejalan dengan bertambahhnya usia. 
Oleh sebab itu tidak boleh malas berolahraga dikarnakan Ovulasi yang tidak berjalan normal karena tubuh yang tidak sehat merupakan salah satu penyebab menopause datang lebih cepat. Meskipun usia bertambah, pastikan tetap menjaga kebugaran dengan berolahraga atau hanya sekedar melakukan perenggangan paling tidak 30 menit setiap hari.

\section{Tidur teratur}

Salah satu cara mengatasi bagi para perempuan pre- menopause ialah tidur teratur. Tidur tidak hanya membuat tubuh merasa lebih baik, tetapi juga memberikan banyak manfaat penting untuk kesehatan secara keseluruhan. Seorang peneliti telah membuktikan bahwa jika cukup tidur yang baik maka mood, hati, otak dan kehidupan seks meningkat secara signifikan. Tidur memainkan peran penting dalam fungsi kekebalan tubuh, metabolisme, kemampuan belajar dan fungsi tubuh vitallainnya. Dengan demikian tidur teratur sangat penting kesehatan fisik dan emosional, dan tidak bisa meremehkan manfaat isitirahat yang teratur setiap hari

\section{b. Cara Pendampingan Pastoral}

\section{Percakapan Pastoral}

Percakapan pastoral adalah salah satu bentuk yang dipakai oleh gembala sebagai alat untuk mendampingi jemaat. Melalui percakapan, gembala dan jemaat memiliki hubungan komunikasi yang baik dan juga jemaat dapat terbuka kepada gembalanya. Tujuan dalam percakapan pendampingan pastoral adalah sebagai alat untuk menghubungi, mengkomunikasikan, membicarakan dalam menolong dan membimbing orang yang sedang dalam masalah. Melalui percakapan gembala dapat mewujudkan kasihnya, perhatiannya terhadap jemaat yang digembalakannya. Percakapan pastoral juga harus dilakukan secara intensif supaya gembala dapat sungguh-sungguh mengenal jemaat yang dilayani tersebut.

\section{Perkunjungan}

Kunjungan pastoral secara positif mencakup konseling. Menurut peneliti, fungsi utama kunjungan pastoral dalam pertumbuhan rohani adalah membantu jemaat untuk menyelami pengalaman hidup mereka, dan selanjutnya mengaitkan pengalaman itu dengan iman mereka. Hal itu akan tercapai bila ada kesediaan baik pada pihak gembala maupun anggota jemaat untuk memperhatikan dengan sungguh-sungguh "sisi dalam" dari pengalaman hidup mereka. Kesediaan untuk membagikan perasaan yang terluka, rasa malu, dan juga sukacita akan mengungkapkan sisi dalam itu. Untuk itu, Gembala perlu peka memperhatikan isyarat-isyarat baik lisan maupun gerakkan yang menunjukkan kesediaan seorang jemaat untuk membicarakan suatu hal yang penting. Dalam perkunjungan ini juga Gembala bertanya dengan lemah lembut, namun sungguh-sungguh untuk mengetahui kehidupan dan iman jemaat tersebut.

\section{Pemberitaan Firman dan Edukasi}

Pemberitaan Firman Allah perlu diterapkan kepada perempuan yang masuk ke face pra-menupause yang bertujuan untuk mengarahkan dan membimbing setiap orang kepada pemahaman dan pengenalan yang mendalam akan tugas dan tanggungjawabnya sebagai perempuan berdasarkan norma Kristen, kepada diri sendiri, keluarga dan masyarakat serta menyerahkan diri mereka dengan sepenuhnya dibawah pimpinan Roh Kudus dan sekaligus menjadi penurut-penurut Allah, seperti anak-anak yang kekasih (Ef. 5: 1).

Pemberitaan Firman Allah kepada perempuan yang masuk fase pra-menupause mencakup kepada pengajaran. Peran Gembala harus mampu menerapkan hal di atas 
sehingga setiap perempuan siap untuk menerima dan siap untuk masuk ke dalam fase pra-menupause.

Edukasi sangat perlu diberikan sebagai pendampingan pastoral karena sejak dini setiap perempuan sudah mendapatkan informasi pengajaran baik dari kesehatan maupun pernyataan kebenaran firman Tuhan untuk menolong mengatasi fase itu jika diperhadapkan.

\section{Kesimpulan}

Berdasarkan penjelasan dari uraian di atas, penulis menyimpulkan bahwa penggembalaan bagi perempuan yang mengalami Fase Pre-Menopause, adalah sebuah hal yang penting bagi seorang hamba Tuhan (konselor) terhadap umat gembalaannya. Dimana ini sangat penting sekali, dikarenakan ada beberapa orang atau lebihnya seorang perempuan mungkin merasa terbaikan, dan arena itu ia mengalami suatu depresi dalam hidupnya, itu juga yang menjadi tekanan dalam batinnya. Hal inilah yang patut diperhatikan oleh seorang gembala untuk menyelamatkan umat gembalaannya dari keterpurukan hidup yang dialami.

Maka dilihat dari model pelayanan terhadap perempuan yang mengalami fase pre-menopause, seorang gembala harus mampu memberikan suatu dampak untuk dapat mengubah paradigma umat gembalaannya, bahwa semuanya itu harus berlandaskan oleh kuasa otoritas Tuhan, dan melalui pelayanan yang dilakukan bisa mampu membangkitkan damai dalam hati dan sukacita hidup kembali.

Oleh karena itu gembala dituntut harus memiliki kepekaan terhadap keadaan yang sedang dialami oleh setiap domba-dombanya. Karena gembala yang baik pasti mengenal dan mengetahui kebutuhan domba gembalaannya. 


\section{Daftar Pustaka}

Anthony A. Hoekema, Manusia Ciptaan Menurut Gambar Allah, (Surabaya: Momentum, 2008), 99.

Charles C. Ryrie, Teologi Dasar 1, (Yogyakarta: ANDI, 2008), 276

Anthony A. Hoekema, Manusia Ciptaan Menurut Gambar Allah, (Surabaya: Momentum, 2008), 99.

Kamus Besar Bahasa Indonesia Elektronik

Https//Carapedia.com/ pengertian definisi Wanita info/ 2141

Https//Carapedia.com...,

Kamus Umum Bahasa Indonesia Edisi Kelima, Aplikasi luring resmi Badan Pengembangan Dan Pembinaan Bahasa, Kementrian Pendidikan Dan Kebudayaan Republik Indonesia.

Jl. Ch. Abineno, Pendampingan Pastoral, (Jakarta: BPK Gunung Mulia, 2001), 9.

Steward Hiltner, Teologi Dan Praksis Pastoral: Ontologi Teologi Pastoral (Ed) Prof. Tj.

G. Holmes, Jakarta: BPK Gunung Mulia Dan Yogyakarta: Penerbit Kanisius, 72-73

E.P. Ginting, Konseling Pastoral: Pengembangan Kontekstual, (Badung: Bina Media Imformasi, 2009), 11.

M. Bons-Storm. Apakah Penggembalaan itu: Petunjuk praktis Pelayanan Pastoral, (Jakarta: BPK Gunung Mulia, 1988), 19. 